Transportation Research Forum

Book Review: The Privatization of Roads and Highways: Human and Economic Factors

Book Author(s): Walter Block

Review Author(s): Gabriel Roth

Source: Journal of the Transportation Research Forum, Vol. 49, No. 1 (Spring 2010), pp. 113-114

Published by: Transportation Research Forum

Stable URL: http://www.trforum.org/journal

The Transportation Research Forum, founded in 1958, is an independent, nonprofit organization of transportation professionals who conduct, use, and benefit from research. Its purpose is to provide an impartial meeting ground for carriers, shippers, government officials, consultants, university researchers, suppliers, and others seeking exchange of information and ideas related to both passenger and freight transportation. More information on the Transportation Research Forum can be found on the Web at www.trforum.org. 
Block, Walter. The Privatization of Roads and Highways: Human and Economic Factors. Forward by Brad Edmonds. Auburn, AL: Ludvig von Mises Institute, 2009. ISBN 978-1-933550-04-6.

\title{
The Privatization of Roads and Highways
}

\author{
by Gabriel Roth
}

Those attempting to improve road conditions tend to start by seeing the problem as a shortage of road capacity. Further reflection, especially by students of economics, leads to the supposition that the problem might often be one of inadequate pricing, especially in congested urban areas. Better pricing has the advantage of helping to solve three problems: it can reduce the demand for road space while simultaneously identifying opportunities for capacity expansion and attracting the necessary finance.

However, many who support better road pricing — that is, pricing based on the relevant costs - have been disappointed at the slow progress of its application. The cities applying the concept to their road networks can be counted on the fingers: Singapore, Bergen, Trondheim, Oslo, London and Stockholm. Might this slow progress be associated with the government ownership of roads, which can lead road users to regard better road pricing as just another tax?

Further reflection, then, leads to the consideration that the critical missing element in dealing with road problems might be not the inadequacy of road pricing but, more fundamentally, the lack of private ownership of roads. And this is the view expounded by Walter Block, privatization expert and pioneer of road privatization, in his new book.

In the introduction (page xvi), Block describes the organization of his book:

The basic theory of privatization, specifically as applied to roadways, is put forth. The case on behalf of commercializing this sector of the economy is made on the basis of improving road safety and decreasing traffic congestion. Next, this theory is applied to a whole host of related issues, such as automobile insurance, holding parades on public streets, and immigration. Then, we focus on the very complex process of getting to there from here: what are the problems of transition, how would the authorities move from a situation under their control to market determination, etc.? The next part of the book is given over to dealing with objections to the foregoing.

In part I of the book, "The Theory" (page 13), Block summarizes the reasons for privatization: First and foremost is the fact that the present government ownership and management has failed. The death toll, the suffocation during urban rush hours and the poor state of repair of the highway stock are all eloquent testimony to the lack of success which has marked the reign of government control.

In making the case for privatization, Block, who (on page 405) describes himself as "a theoretical economist," relies mainly on general principles. For example, he argues (on pages 1213) that private ownership has the advantage of an "automatic reward and penalty system imposed by profits and losses ... Because this is well known, we have entrusted the market to produce the bulk of our consumer goods and capital equipment ... This analysis applies to the provision of roads no less than to fountain pens, frisbees or fishsticks."

He seems less interested in the politicization brought about by governmental controls, such as the diversion of funds from the U.S. Federal Highway Trust Fund, the financing of "roads to nowhere," and the thousands of earmarks to help legislators get themselves re-elected at the expense of road users. 
Part I contains the important chapter "Public Goods and Externalities: The Case of Roads," first published in 1983. Externalities, which can be positive or negative, constitute benefits (or costs) affecting people "external" to those directly involved in a transaction. This topic is of special interest today as the externalities mentioned by Block are mostly positive, and are discussed in the book as an obstacle to privatization, because the private sector would not invest enough in roads. Currently the only externalities discussed in relation to roads are negative ones, e.g. congestion, pollution and greenhouse gas emissions.

Block is appalled at the high number of deaths on roads, which now exceed a million a year worldwide. He feels so strongly about this that he describes those involved in preventing highway privatization as "government criminals" (page 344). But he presents no convincing evidence that deaths on privately provided roads would be substantially fewer than on government roads.

Part II, "Applications," discusses matters incidental to privately-provided roads, such as competition between them, automobile insurance, price controls, traffic safety, and discrimination against certain classes of road users.

Part III, "Process," seeks to answer the question (page 239): "What, then, is the best process for converting vehicular thoroughfares from the public to the private sector?"

Block discusses alternative ways of doing this, including selling roads to the highest bidder (rejected) and returning them to known original owners (preferred). The author concludes that, in the case of urban areas, giving the roads to groups of local property owners could be the best solution. This section also deals with the difficulties private road providers have in competing with governmental "free" roads, and concludes (page 270) that, "from a libertarian perspective, ... all roads should be commercialized at once; then, this problem would cease to exist."

While Block can be dogmatic about the objective of privatizing roads, he is flexible about how to do so. He writes in this section that he has "no hard and fast conclusion as to the best way to privatize streets and highways" (page 252).

Part IV, "Critiques," discusses objections to privatization. For example, the first (page 293) concerns Gordon Tullock's objection that a privately owned road stretching from Boston to Los Angeles would effectively split the USA into separate halves. While this point might seem esoteric, even irrelevant, it actually covers the important issues of inter-connections between privately owned roads and rights to cross them.

The weakness of this interesting volume is that two thirds of the chapters are reprints of early pioneering articles. This inevitably results in much repetition. Some of the chapters were written for libertarian readerships that may have been more interested in "libertarian theology" than in the provision of safe roads for which users want to pay.Another weakness is that the book is not up-todate. Thus, the first chapter, published in 1979, discusses (page 15) motorists "having to stop every few feet and toss a coin into a toll box." Modern readers are likely to know that road tolls can be collected without stopping vehicles, as with collection systems such as "E-Z Pass." Some will even know about the more modern GPS-based systems that enable road use to be paid for as easily as cell-phone use, with road users being debited, and road providers credited, without divulging details of individual journeys.

Walter Block has probably given more thought than anyone to the privatization of roads and highways, and this reviewer has gained much from his writing. Might the author now consider writing a shorter, more up-to-date volume, addressed to a general readership rather than to a libertarian one?

Gabriel Roth, a research fellow at the Independent Institute, has been interested in road pricing and privatization for some 50 years. He is the author of Paying for Roads: The Economics of Traffic Congestion (1967); Roads in the Market Economy (1996); and editor of the award-winning Street Smart - Competition, Entrepreneurship and the Future of Roads (2006). 